\title{
First evidence of multiple resistance of Sumatran Fleabane (Conyza sumatrensis (Retz.) E.Walker) to five- mode-of-action herbicides
}

\section{Camila Ferreira de Pinho* ${ }^{1}$, Jessica Ferreira Lourenço Leal ${ }^{1}$, Amanda dos Santos Souza ${ }^{1}$, Gabriella Francisco Pereira Borges de Oliveira ${ }^{1}$, Claudia de Oliveira ${ }^{1}$, Ana Claudia Langaro ${ }^{1}$, Aroldo Ferreira Lopes Machado ${ }^{1}$, Pedro Jacob Christoffoleti ${ }^{2}$, Luiz Henrique Saes Zobiole ${ }^{3}$}

\author{
${ }^{1}$ Department of Plant Science, Institute of Agronomy, Federal Rural University of Rio de Janeiro (UFRRJ), Seropédica-RJ, \\ Brazil \\ ${ }^{2}$ Department of Crop Science, University of São Paulo (USP), Piracicaba-SP, Brazil \\ ${ }^{3}$ Corteva Agriscience ${ }^{\mathrm{TM}}$, the Agriculture Divison of DowDuPont ${ }^{\mathrm{TM}}$, Dow AgroSciences LLC Mogi-Mirim-SP, Brazil
}

*Corresponding author: camilafepi@ufrrj.br

\begin{abstract}
Herbicide resistance is the evolutionary response of weeds to the selection pressure caused by repeated application of the same active ingredient. It can result from two different mechanisms, known as target site resistance (TSR) and non-target site resistance (NTSR). In addition to single-herbicide resistance, multiple resistance can occur due to herbicides selection or accumulation of resistance genes by cross-pollination. The aim of this research was to investigate the suspect of multiple herbicide resistance of Sumatran Fleabane (Conyza sumatrensis (Retz.) E.Walker) to herbicides frequently used as a burndown application. Dose-responses in a whole-plant assay were carried out to investigate multiple-resistance of Sumatran fleabane to paraquat, saflufenacil, diuron, 2,4-D and glyphosate. Results indicated that the resistance index (ratio $\mathrm{R} / \mathrm{S}$ ) based on herbicide rate to cause $50 \%$ mortality $\left(\mathrm{LD}_{50}\right)$ were $25.51,1.39,7.29,1.84$ and 7.55 for paraquat, saflufenacil, diuron, 2,4-D and glyphosate, respectively. Based on herbicide rate required to cause a $50 \%$ reduction in plant growth $\left(\mathrm{GR}_{50}\right)$, the resistant index were 51.83, 14.10, 5.05, 3.96 and 32.90 for the same herbicides, respectively. Our results confirmed multiple resistance of Conyza sumatrensis from Paraná-Brazil to herbicides from five-mode of-action. This was the first report of Conyza sumatrensis resistant to 2,4-D and the first case of Conyza sumatrensis presenting multiple resistant to herbicides from fivemode of-action in the world.
\end{abstract}

Keywords: Dose-response; herbicide; mode of action; multiple resistance, Sumatran fleabane.

Abbreviations: ae_acid equivalent; ai_active ingredient; ALS_acetolactate synthase; APX_ascorbate peroxidase; DAA_days after application; DAT_days after treatment; EPSPS_5-enolypyruvyl-shikimate-3-phosphate synthase; GR_Glutathione reductase; GR 50 _rate required to cause a $50 \%$ reduction in plant growth; ha_ectare; $\mathrm{kPa}$ _kilopascal; $\mathrm{LD}_{50 \_}$rate required to cause a $50 \%$ mortality; NMR_nuclear magnetic resonance; PPO_protoporphyrinogen oxidase; PSI_photosystem; PSII_photosystem II; R_resistant; RI_resistance index; S_susceptible; TSR_target site resistance; non-target site resistance (NTSR); UPCB_Herbarium of the State University of Paraná.

Introduction

Brazil is one of the largest grain producers in the world due to its extensive arable land and favorable climate for the production. However, weeds cause serious loss due to competition with the crop of interest for essential resources (Swanton et al., 2015; Jha et al., 2017; Gharde et al., 2018). Conyza spp. is currently considered as one of the main weeds in the crop production. Among the Conyza genus, there are nearly 50 species (Kissmann and Groth, 1999) and C. bonariensis, C. canadensis and Conyza sumatrensis (Retz.) E.Walker species have been often associated with cases of herbicide resistance in Brazil. It is a cosmopolitan weed, where minimum soil disturbance associated with fallow, perennial cropping systems, and reduced tillage management practices of annual crops. These factors have provided a favorable niche for the ecological adaptation of Conyzas (Murphy and Lemerle, 2006), as one of the main current weed problems in Brazil.

The occurrence of this plant is concentrated in the late autumn and early spring, which coincides with the fallow or winter growing season (Tozzi and Van Acker, 2014). The absence of plants in the fallow favors the establishment of Conyza spp. in the areas. These species produce many seeds that can spread long distances by wind (Wu et al., 2007; Savage et al., 2014). These biological characteristics and the selection of herbicide- 
resistant biotypes contribute to the wide and increasing dispersion of Conyza spp.

Herbicide resistance causes greater short-term cost to manage weed population, including yield loss, reduced commodity prices because of weed-seed contamination, reduced land values, costs of mechanical and cultural controls, additional expense of alternative herbicides or cropping systems or both for managing the resistant weed. Several recent studies have described the added costs associated with the management of herbicide-resistance weeds (Norsworthy et al., 2012). In Brazil, the presence of herbicide-resistant Conyza spp. increases control costs by $40 \%$. The scenario is even worse with the occurrence of Conyza spp. and Digitaria insularis in the same production area, which increase costs by $200 \%$ (Adegas et al., 2017).

Treatment with herbicides is the primary method of controlling weed populations in modern agriculture. Furthermore, strong selection by herbicides has resulted in widespread evolution of resistance to herbicides in weed populations (Délye et al., 2013; Powles and Yu, 2010). Currently, there are 100 cases of Conyza spp. resistant to herbicides in the world (Heap, 2018). In Brazil, the first report of herbicide-resistant Conyza spp. was observed in 2005, when glyphosate no longer controlled these plants (Moreira et al., 2007; Heap, 2018). Because of glyphosate resistance, ALS-inhibitors herbicides started to be used to control weeds in the soybean crop. In 2011, multiple resistance to both mode of action was reported as a result of the high selection pressure exerted by the ALS-inhibitor herbicides (Santos et al., 2014; Heap, 2018). Populations resistant to glyphosate, ALS-inhibitors and other herbicides are of major concerns because these herbicides are the most effective post-emergence chemicals currently available to growers to manage horseweed in soybean. In addition, in 2016 and 2017, single resistance to paraquat and saflufenacil and multiple resistance to chlorimuron, glyphosate and paraquat were reported (Heap, 2018).

Multiple-herbicide resistance can arise by field selection of herbicides or due to accumulation of resistant genes by crosspollination (Beckie and Tardif, 2012). The multiple resistance to five-herbicides-modes- of-action (5-enolypyruvyl-shikimate3-phosphate synthase (EPSPS) inhibitors, photosystem I (PSI) diverters, photosystem II (PSII) inhibitors, protoporphyrinogen oxidase (PPO) inhibitors and 2,4-D) was reported by farmers who observed no efficiency to control Sumatran fleabane after different herbicide applications in the last growing season at Western region of Paraná State-Brazil. In no-tillage systems, the non-selective herbicides, such as glyphosate, paraquat or saflufenacil, has been widely used. The presence of Conyza sumatrensis requires application of glyphosate $+2,4-\mathrm{D}$ followed by pre-planting spray of paraquat or saflufenacil. This management system is effective for controlling weeds, but when repeated over the years may promote the selection of biotypes with multiple resistance. These escapes in weed control were related to 5-enolypyruvyl-shikimate-3-phosphate synthase (EPSPS) inhibitors, acetolactate synthase (ALS) inhibitors, photosystem I (PSI) diverters, photosystem II (PSII) inhibitors and protoporphyrinogen oxidase (PPO) inhibitors and 2,4-D.
The aim of this research was to investigate the first case of multiple resistance of Conyza sumatrensis to herbicides from five-mode-of action frequently used as a burndown application prior to soybean planting.

\section{Results}

The dose-response assay showed $100 \%$ mortality in the $C$. sumatrensis - $\mathrm{S}$ biotype. On the other hand, the $\mathrm{R}$ biotype was significantly less affected by herbicides and it was required higher doses than normal. The $L_{50}$ and $G_{50}$ values for $R$ plants were higher for $\mathrm{S}$ biotype (Fig. 1 to 5; Table 1).

\section{Paraquat dose-reponse}

Paraquat controlled $100 \%$ of S plants. In contrast, R plants were not controlled even at the $16 \mathrm{X}$ rate $\left(6,400 \mathrm{~g}\right.$ a.i. ha $\left.{ }^{-1}\right)$. Paraquat $L_{50}$ values were 38.24 and $975.59 \mathrm{~g}$ a.i. ha ${ }^{-1}$ for $\mathrm{S}$ and $\mathrm{R}$ plants, respectively. Even the highest paraquat dose used in the dose-response assay could not kill the $R$ plants. The maximum control for $R$ plants was $57 \%$. The $G_{50}$ values for paraquat showed that the dose needed to reduce $50 \%$ of dry mass was 159.17 and 8,249.65 $\mathrm{g}$ a.i. ha ${ }^{-1}$, for $\mathrm{S}$ and $\mathrm{R}$ biotype, respectively (Fig. 1). The resistance index (R/S) was calculated from $L_{50}$ and $G R_{50}$ values and showed that $R$ biotype was 25.51 and 51.83 -fold more resistant than S plants (Table 1 ).

\section{Saflufenacil dose-response}

The $\mathrm{S}$ biotype was $100 \%$ controlled by saflufenacil. For the $\mathrm{R}$ plants more than $8 \mathrm{X}$ dose (560 $\mathrm{g}$ a.i. ha ${ }^{-1}$ ) was required to satisfactorily control the weed. The dry mass of $S$ plants was reduced to less than $10 \%$ with $2 X$ dose $\left(140 \mathrm{~g}\right.$ a.i. ha ${ }^{-1}$ ), while $8 X$ could reduce about $50 \%$ dry mass of $R$ plants. Saflufenacil $\mathrm{LD}_{50}$ values were 13.19 and $18.36 \mathrm{~g}$ a.i. ha ${ }^{-1}$ for $\mathrm{S}$ and $\mathrm{R}$ plants, respectively. The $G R_{50}$ values for saflufenacil showed that the dose needed to reduce $50 \%$ of dry mass was 45.29 and 638.93 g a.i. ha ${ }^{-1}$, for $S$ and $R$ biotype, respectively (Fig. 2). Based on the $L D_{50}$ and $G R_{50}$ values, the resistance index reveled that $R$ population was 1.39 and 14.10 -fold less responsive to saflufenacil compared to S plants (Table 1).

\section{Diuron dose-response}

Diuron controlled $100 \%$ of $S$ plants. On the other hand, $\mathrm{R}$ plants were controlled only when $8 \mathrm{X}\left(16,000 \mathrm{~g}\right.$ a.i. ha $\left.{ }^{-1}\right)$ was applied. The $\mathrm{LD}_{50}$ values for diuron were 534.88 and $3,900.53 \mathrm{~g}$ a.i. $\mathrm{ha}^{-1}$ for $\mathrm{S}$ and $\mathrm{R}$ plants, respectively, while the $\mathrm{GR}_{50}$ values ranged from $1,035.16$ to $5,227.16 \mathrm{~g}$ a.i. ha ${ }^{-1}$ for $S$ and $R$ plants, respectively (Fig. 3). The resistance index (R/S) calculated from $\mathrm{LD}_{50}$ and $\mathrm{GR}_{50}$ values showed that $\mathrm{R}$ biotype was 7.29 and 5.05fold more resistant than $S$ plants (Table 1).

\section{2,4-D dose response}

The herbicide 2 ,4-D conferred $100 \%$ of control to S plants. On the other hand, R plants were controlled only when $8 \mathrm{X}$ applied 
$\left(8,040 \mathrm{~g}\right.$ a.e. $\left.\mathrm{ha}^{-1}\right)$. Considering the biomass, $2 \mathrm{X}$ dose was enough to reduce the dry mass to zero in the $S$ biotype, while we needed $8 \mathrm{X}$ to obtain similar results in $\mathrm{R}$ plants. The $\mathrm{LD}_{50}$ values for 2,4-D were 371.97 and $686.01 \mathrm{~g}$ a.e. ha ${ }^{-1}$ for $S$ and $R$ plants, respectively, while the $\mathrm{GR}_{50}$ values were $1,495.67$ and $5,918.67 \mathrm{~g}$ a.e. $\mathrm{ha}^{-1}$ for $\mathrm{S}$ and $\mathrm{R}$ plants, respectively (Fig. 4). The resistance index calculated based on $\mathrm{LD}_{50}$ and $\mathrm{GR}_{50}$ showed that $\mathrm{R}$ biotype was 1.84 and 3.96 more resistant than $\mathrm{S}$ plants (Table 1).

\section{Glyphosate dose-response}

The S plants showed high susceptibility to glyphosate with $95 \%$ control at $0.5 \mathrm{X}$ dose. The maximum control for $\mathrm{R}$ plants was reached only when $16 \mathrm{X}\left(11,520 \mathrm{~g}\right.$ a.e. $\left.\mathrm{ha}^{-1}\right)$ applied, showing high resistance level. The dry mass of $S$ plants was reduced to zero even $0.5 X$ dose applied. For the $\mathrm{R}$ plants, $100 \%$ of dry mass reduction was observed only under the highest dose. Glyphosate $L_{50}$ values were 52.67 and $397.77 \mathrm{~g}$ a.e. ha ${ }^{-1}$ for $\mathrm{S}$ and $R$ plants, respectively. Based on dry mass reduction, $\mathrm{GR}_{50}$ estimated for $S$ and $R$ plants was 121.02 and 3,981.13 g a.e. ha ${ }^{1}$, respectively (Fig. 5). The resistance index (R/S) calculated from $L D_{50}$ and $G R_{50}$ values showed that $R$ biotype was 7.55 and 32.90-fold more resistant than $\mathrm{S}$ plants (Table 1 ).

\section{Confirmation criteria}

The population of Conyza sumatrensis meets all the criteria set to confirm a new case of multiple resistance to paraquat, saflufenacil, diuron, 2,4-D and glyphosate (Heap 2005). Criterion 1: the plants from these populations have survived and reproduced after their exposure to a herbicide dose that was lethal to the susceptible population; Criterion 2: the resistance factors were high and the recommended dose to the species did not provide satisfactory control; Criterion 3: the plants from the F2 generation of these populations were considered resistant; Criterion 4: escaped plants are being observed on the field; Criterion 5: random plants of these population were properly classified as Conyza sumatrensis.

\section{Discussion}

The Conyza spp. control strategy has used a burndown application of glyphosate associated with 2,4-D, followed a sequential application of a contact herbicide, such as paraquat, paraquat+diuron or saflufenacil (Werth et al., 2010; Peterson et al., 2017). This strategy has been widely used to Conyza spp. control, but unfortunately reports of herbicides resistant are now occurring.

A dose-response experiment not only determines the discriminating dose for large-scale resistance testing as mentioned in the previous section, but also evaluates the highest dose that a population can tolerate and to obtain clues for the potential resistance mechanism(s). High resistance level may not only indicate targeted genetic point mutation, but also could be indicative of nontarget site resistance mechanism (Burgos et al., 2015). The $R / S$ ratios of $L D_{x x}$ or $G R_{x x}$ values are used to compare the magnitude of resistance of different populations (Burgos et al., 2013).

Evolved resistance to paraquat has been reported in 68 biotypes of 32 weed species in 18 countries. Nineteen of these resistant biotypes are from Conyza species (horseweeds and fleabanes) (Heap, 2018). The $S$ biotype, at all rates, and $R$ plants sprayed with 8 and $16 \mathrm{X}$ displayed rapid desiccation and necrosis, but the $\mathrm{R}$ plants recovered two weeks after treatment, while the $S$ plants were died. Some reports of Conyza spp. exhibit the level of paraquat resistance values ranging from 9 to 352.5 -fold, when compared with $\mathrm{S}$ populations (Van Gessel et al., 2006; Eubank et al., 2012; Moretti et al., 2017). In the present study, the $\mathrm{R}$ biotype showed resistant index of 25.51 and 51.83 -fold based on $L_{50}$ and $G R_{50}$, respectively.

The ratio of paraquat resistance between $R$ and $S$ biotypes ranged from 10 and 30 -fold at vegetative rosette stage to 100 fold or more after 10 weeks, when plants were entered their reproductive cycle (Ye and Gressel, 2000). It makes the control of weeds more difficult at the advanced stages. Current understanding of the molecular mechanism of paraquat resistance in higher plants includes sequestration of paraquat to the vacuoles and/or enhanced activity of antioxidative enzymes (Szigeti, 2005). Although sequestration into the vacuole remains the best hypothesis to account high-level paraquat resistance that is inherited as a semi-dominant single gene trait, multiple mechanisms governed by more complex inheritance might combine to confer tolerance at a lower level (Hawkes, 2014).

Saflufenacil is effective against plants that are difficult to control, such as Conyza spp. It has been widely used as a strategy to control Conyza spp. resistant to glyphosate and paraquat plants (Mellendorf et al., 2013; Waggoner et al., 2013; Moretti et al., 2015). However, as observed in this study, weed populations from Brazil showed resistance indexes of 1.39 and 14.10to saflufenacil, based on $L_{50}$ and $G R_{50}$, respectively. A common approach to manage herbicideresistant weeds is to shift to alternative herbicides or herbicide mixtures that still effectively control the resistant populations, or as part of program that integrates PRE herbicides along with POST-applied (Beckie, 2006).

There are a few cases of PPO-inhibitor resistance already reported. The first case was the multiple resistance of Amaranthus tuberculatus (Tall waterhemp) to ALS and PPOinhibitors in the United States recorded in 2001. So far, thirteen species were identified worldwide. Only three biotypes were reported as resistant to saflufenacil, all of them in Brazil, including Euphorbia heterophylla in 2004 and Conyza sumatrensis in 2017 (Heap, 2018). The resistance mechanism to saflufenacil remains unknown, but resistance to PPOherbicides in Amaranthus spp. was attributed to a target-site mutation in the PPX2 gene only, characterized by a Gly-210 deletion (Patzoldt et al., 2006, Salas et al., 2016; Salas-Perez et al., 2017).

PSII inhibitors block electron transfer to the secondary QB plastoquinone (QB-site) acceptor of the D1 subunit protein, resulting in interruption of electron transfer from the primary plastoquinone site (QA-site) to QB (Powles and Yu, 2010). The interrupted electron transfer causes oxidative stress by production of reactive oxygen species, which cause rapid cellular degradation (Menne, 2005). There are currently nine biotypes resistant to diuron herbicide. The first case was reported in 1987, when Chloris barbata was identified in the United States. 
Table 1. The $\mathrm{LD}_{50}, \mathrm{GR}_{50}$ and resistance index (RI) values for the dose-response assay.

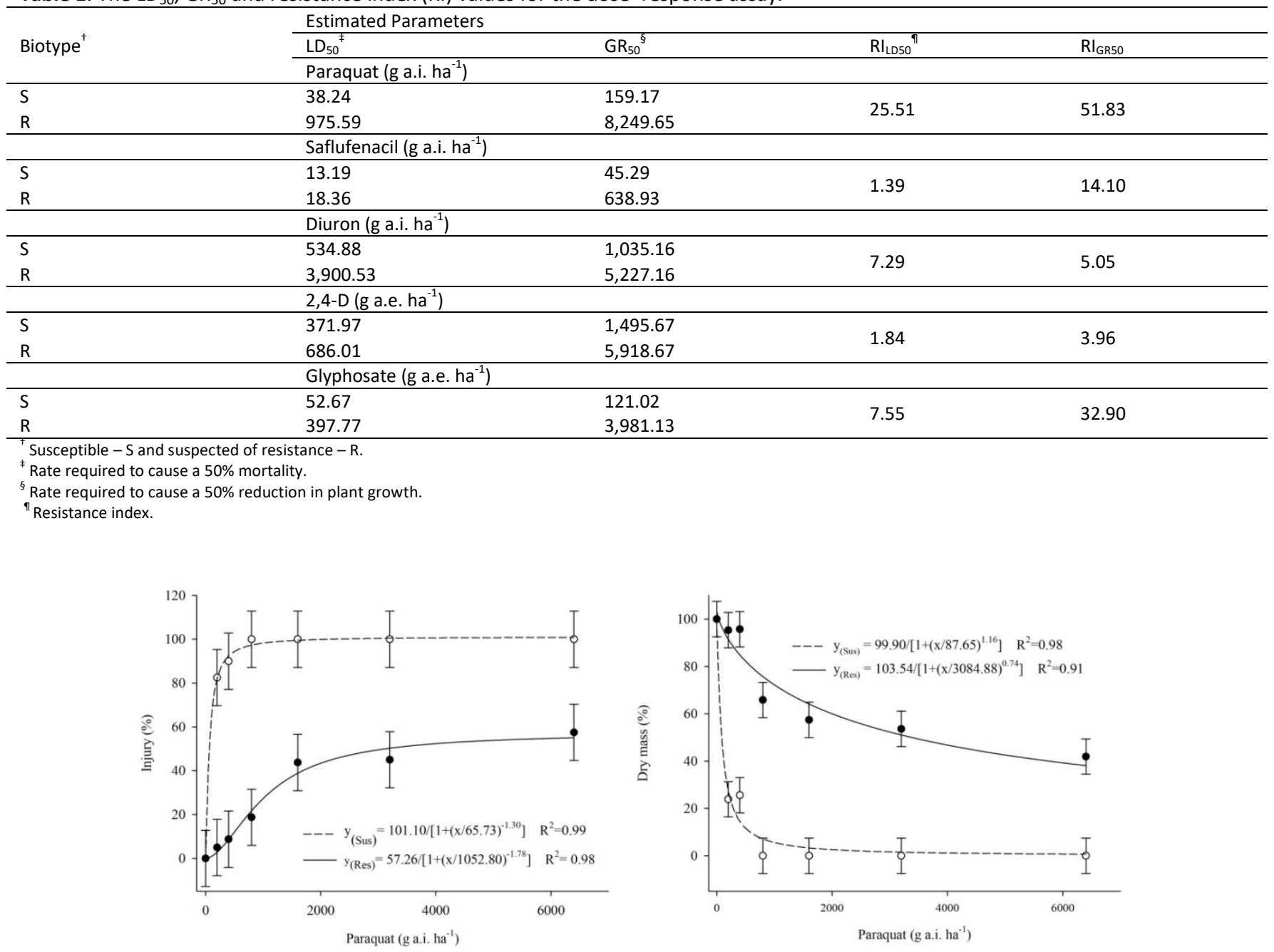

Fig 1. Injury and dry mass observed by dose-response assay of herbicide resistant (R) and susceptible (S) Conyza sumatrensis plants treated with paraquat at 28 days after herbicide application.
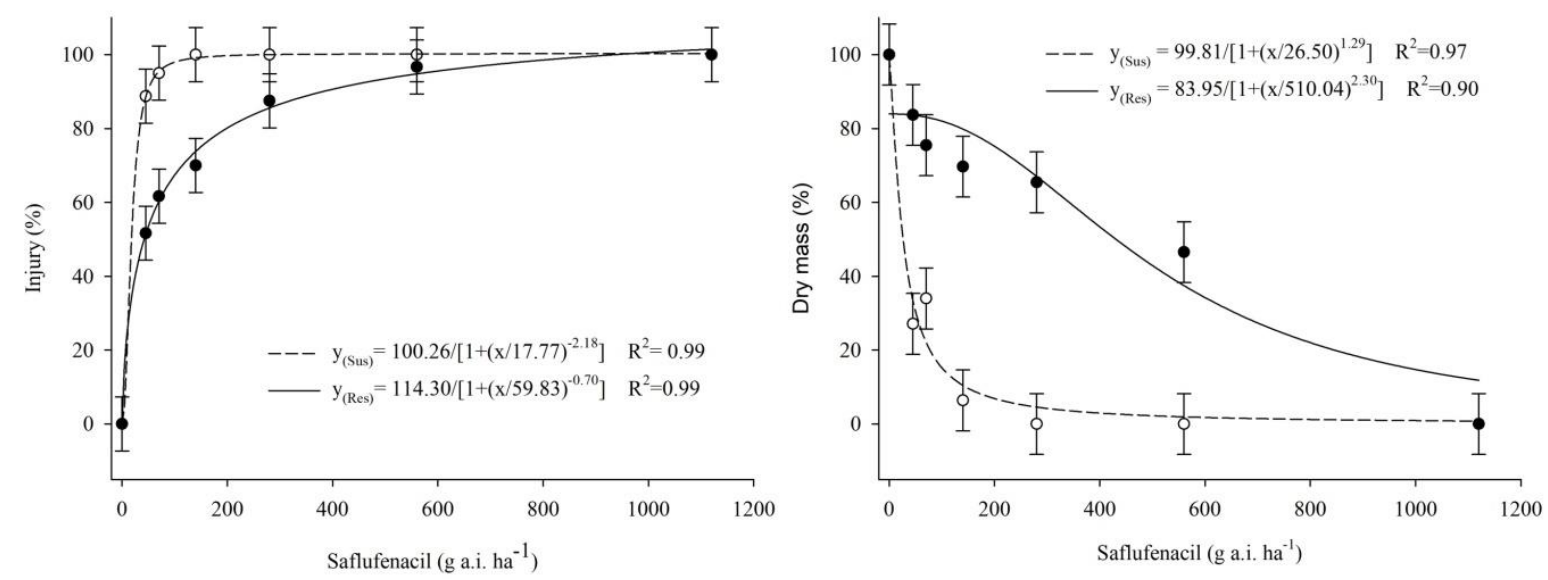

Fig 2. Injury and dry mass observed by dose-response assay of herbicide resistant (R) and susceptible (S) Conyza sumatrensis plants treated with saflufenacil at 28 days after herbicide application. 

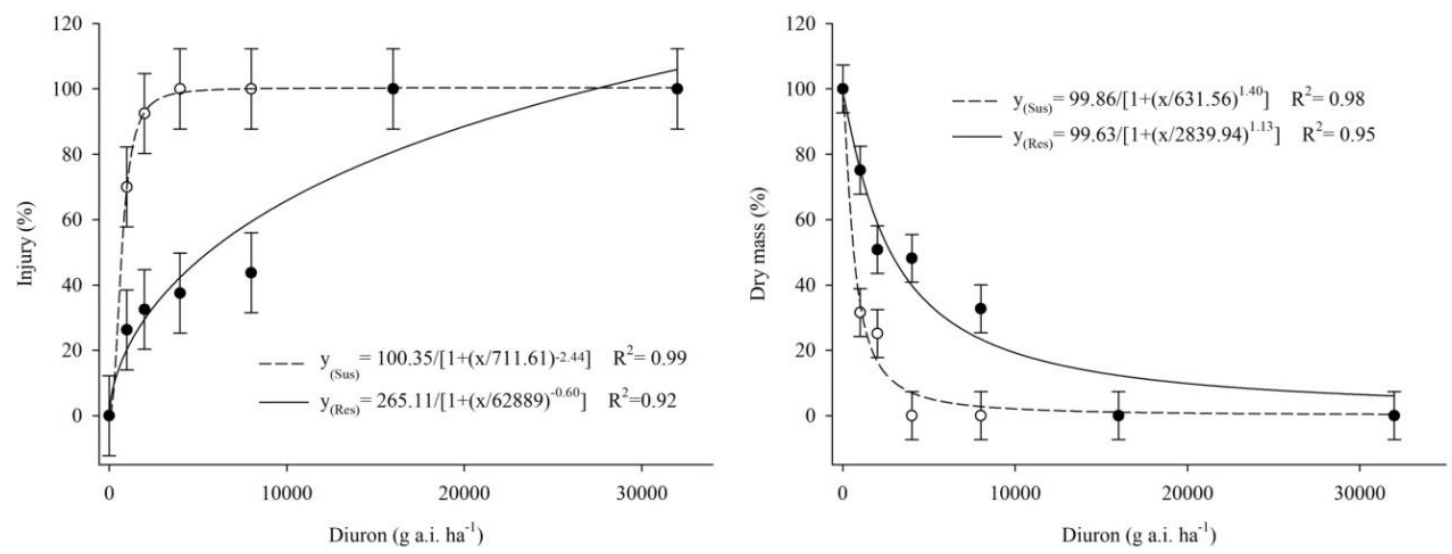

Fig 3. Injury and dry mass observed by dose-response assay of herbicide resistant (R) and susceptible (S) Conyza sumatrensis plants treated with diuron at 28 days after herbicide application.
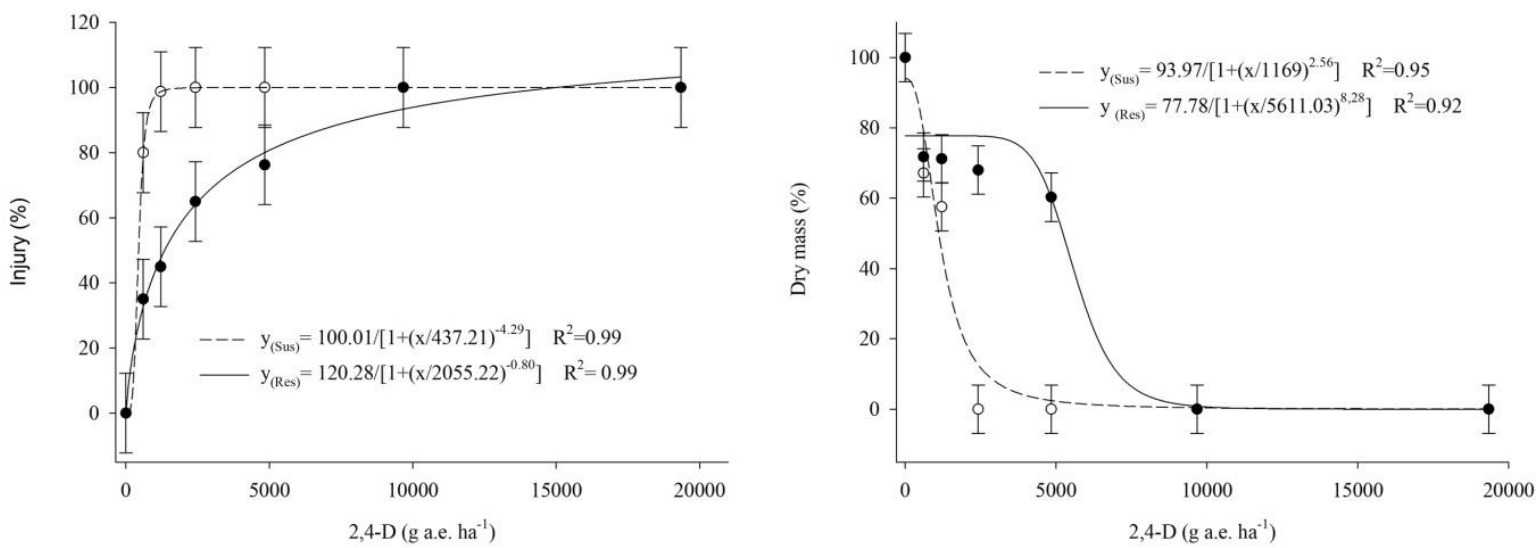

Fig 4. Injury and dry mass observed by dose-response assay of herbicide resistant (R) and susceptible (S) Conyza sumatrensis plants treated with 2,4-D at 28 days after herbicide application.
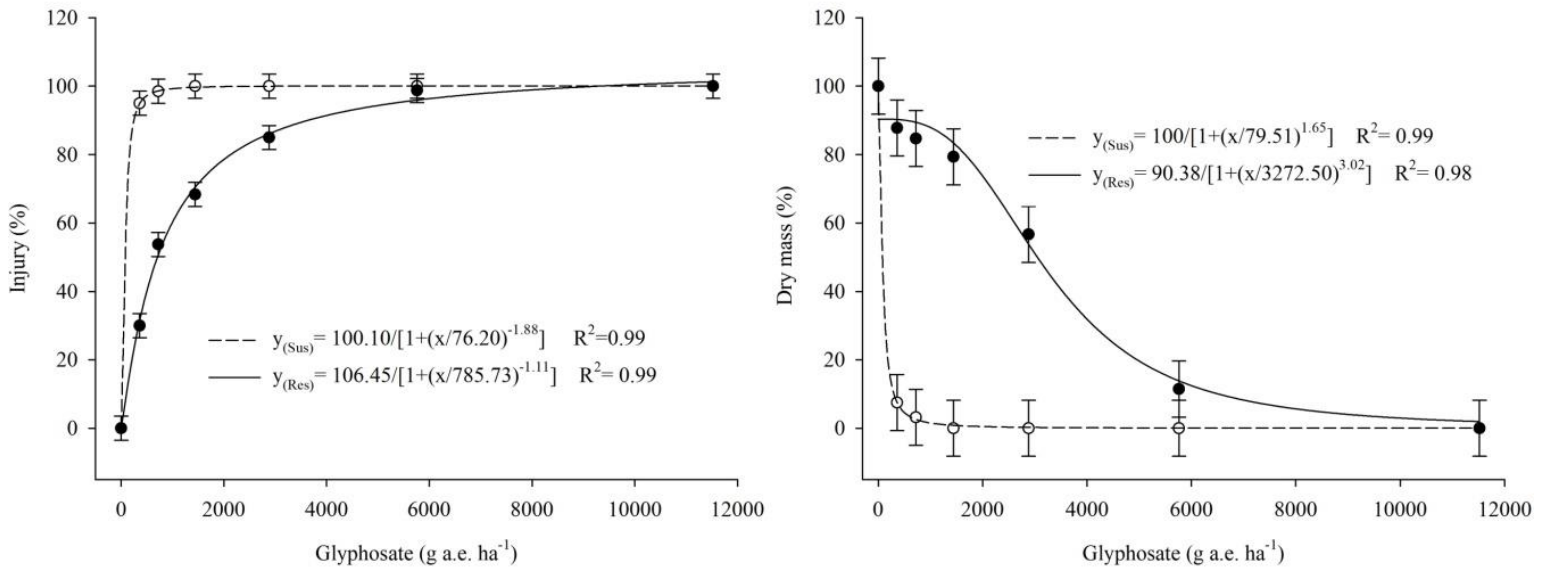

Fig 5. Injury and dry mass observed by dose-response assay of herbicide resistant (R) and susceptible (S) Conyza sumatrensis plants treated with glyphosate at 28 days after herbicide application. 
In 2002, cross-resistance to PSII-inhibitors including atrazine, simazine and diuron was reported in Conyza canadensis present in blueberry fields (Heap, 2018). Our study is the first case of Conyza sumatrensis resistant to diuron worldwide with resistance index of 7.29 and 5.05 , based on $L_{50}$ and $G_{50}$, respectively.

So far, sequencing of the $p s b \mathrm{~A}$ gene has indicated two mutations point: $\mathrm{Ser}_{264} \mathrm{Gly}$ and $\mathrm{Val}_{219} \mathrm{lle}$, responsible for resistance to PSII inhibitors (Mengistu et al., 2000; Perry et al., 2012). Ser ${ }_{264}$ Gly mutation confers cross-resistance to other PSII-inhibiting herbicides, such as triazolinone family (Dayan et al., 2009; Perry et al., 2012; Yu et al., 2013), while Val ${ }_{219}$ lle substitution have also been correlated to resistant to diuron and metribuzin (Mengistu et al., 2000). The non-target site resistance (NTSR) to PSII-inhibiting herbicides has been related to increased levels of herbicide detoxification in velvetleaf (Abutilon theophrasti Medik.) (Yuan et al., 2007), and Cytochrome P450 monooxygenases can provide resistance to multiple herbicides, including PSII inhibitors simazine and metribuzin in rigid ryegrass (Preston et al., 1996; De Prado et al., 1997; Preston, 2003).

The first cases of evolved herbicide resistance were to one of the first commercialized synthetic herbicides, 2,4-D. Wild carrot (Daucus carota L.) (Switzer, 1957) and spreading dayflower (Commelina diffusa Burm.) (Hilton, 1957) were both reported to have evolved resistance to 2,4-D in 1957, around 10 years after the use of 2,4-D had become widespread. Currently, there are 38 species resistant to synthetic auxins and 22 are resistant to 2,4-D (Heap, 2018). In this study, we identified the first case of Conyza sumatrensis resistant to 2,4$D$ in the world, with resistance index of 1.84 and 3.96, respectively, based on $\mathrm{LD}_{50}$ and $\mathrm{GR}_{50}$. The resistant biotype shows rapid desiccation after herbicide spray. In about 6 hours, the old leaves of resistant biotype showed necrosis while the susceptible did not show any symptom. Later, the susceptible plants developed typical symptoms of auxin herbicides while the young leaves of resistance plants remained intact. This response could be related to low herbicide translocation, allowing the plants to survive and ensuring resistance to this herbicide. This phenomenon was already reported, but it was associated with glyphosateresistance in Ambrosia trifida (Van Horn et al., 2017; Moretti et al., 2018) and called as rapid-necrosis symptom.

Glyphosate is one of the most widely used herbicides. The intensive use of glyphosate (no-till, fallow and/or glyphosate tolerant crops) has resulted in the evolution of glyphosateresistant worldwide (Powles, 2008; Beckie and Harker, 2017). Glyphosate-resistant biotypes of $C$. bonariensis, $C$. canadensis and $C$. sumatrensis have been reported in many countries, including Brazil. There are currently 300 unique cases of glyphosate-resistant weeds in the world, including 62 Conyzas. The first case of Conyza resistant to glyphosate was observed in the United States, in 2000. In Brazil, both C. bonariensis and C. canadensis were reported as glyphosate-resistant in 2005. Later, in 2010, C. sumatrensis was also reported as resistance to glyphosate (Heap, 2018). In this study, a glyphosateresistant biotype was identified with higher resistance level, about 7.55 and 32.90-fold, based on $\mathrm{LD}_{50}$ and $\mathrm{GR}_{50}$ respectively. The level of glyphosate-resistance Conyza spp. for biotype $\mathrm{R}$ was 2.5-12-fold, when compared with S (Eubank et al., 2012; Kumar et al., 2017). In Brazil, the glyphosateresistance level ranged from 1.96 to 4.08 (Santos et al., 2014). Also, the multiple resistance levels ranging from 1.66 to 6.74 and from 18.93 to 47.02 for glyphosate and chlorimuron-ethyl, respectively were observed (Santos et al., 2014b).

Glyphosate-resistance mechanisms includes target-site mutation, target-site gene duplication, active vacuole sequestration, limited cellular uptake and a rapid necrosis response (Sammons and Gaines, 2014). Currently, the resistance mechanisms to glyphosate in Conyza spp. was identified as the substitution of proline to serine in the codon 106 (Amaro-Blanco et al., 2018; Page et al., 2018), overexpression of epsps gene and $A B C$ transporters (Ge et al., 2011; Tani et al., 2015) and reduced herbicide translocation (Nol et al., 2012; Gonzalez-Torralva et al., 2014, 2017; Kleinman and Rubin, 2017). Calvin cycle enzymes and proteins of unknown function were also identified as possible candidates involved to glyphosate-resistance Conyza canadensis (Gonzalez-Torralva et al., 2017).

Target-site mutations for glyphosate resistance endow lower levels of resistance than target-site mutations for some other mechanisms of action (Preston et al., 2009). A double mutation found recently in some weeds, $\mathrm{PrO}_{106} \mathrm{Ser}$ and $\mathrm{Thr}_{102}$ lle, greatly increases resistance levels (Yu et al., 2015). Pro106 target-site mutations normally act together with reduced translocation to provide higher-level of resistance (Kaundun et al., 2011; Bostamam et al., 2012; Nandula et al., 2013; Gonzalez-Torralva et al., 2014). Experiments using nuclear magnetic resonance (NMR) to observe glyphosate in vivo entering cells and cellular compartments have identified a new resistance mechanism that result in restricted translocation correlated with the glyphosate resistance. The difference in glyphosate vacuole sequestration rates between resistant and susceptible $C$. canadensis was about $10 \mathrm{X}$ (Ge et al., 2014). A whole-plant assay in the cold $\left(8^{\circ} \mathrm{C}\right)$ demonstrated that vacuole sequestration was inhibited. In this situation, resistant plants of $C$. canadensis were become susceptible to glyphosate (Ge et al., 2011). This demonstrated that the resistance was due to the vacuolar sequestration and that physiological properties of the resistance mechanism could be utilized as a mechanism to reverse the resistance.

\section{Impact on weed management}

The large difference in the R/S $L D_{50}$ and $\mathrm{GR}_{50}$ ratio obtained for paraquat, saflufenacil and glyphosate response in this Conyza sumatrensis population indicates that the potential resistance mechanism(s) may incur fitness cost in the presence of herbicide. In view of the confirmation of resistance, proactive resistance management strategies should be proposed, predicting the behavior of other herbicides to control these species. Herbicides should be used wisely (e.g. in rotation or mixture) and in combination with other nonchemical control options.

Integrated weed management practices should be adopted in regions of existence or potential existence of multiple-resistant Conyza spp. including the use of cover crops, management of weed seed bank, usage of herbicides with different 
mechanisms of action in the same spray tank, and the appropriate and accurate application of herbicides (Norsworthy et al., 2012). Herbicide resistance screening and monitoring should be adopted by farmers since multiple resistance is challenger and present additional risks.

\section{Materials and Methods}

\section{Plant material}

Samples originated from failures in weed control were collected from the field with history of herbicide application including several applications of glyphosate, 2,4-D, paraquat+diuron and saflufenacil to confirm the resistance to paraquat. The survived plants were self-pollinated and the $F_{1}$ seeds of $C$. sumatrensis from plants were identified as resistant to paraquat and also to saflufenacil (Heap, 2018). These plants were selected and grown in greenhouse for the production of the F2 generation seeds, with the objective to complete a dose-response assay with herbicides that included different modes of action. The original collection site was in Assis Chateaubriand-Paraná, Brazil (2416 $\left.16^{\prime} 53.8^{\prime \prime S} 53^{\circ} 30^{\prime} 47.5^{\prime \prime} \mathrm{W}\right)$. Another population suspected to be susceptible to all mode of actions were collected from Rio de Janeiro.

The seeds were sown in $2.5 \mathrm{dm}^{-3}$ pots filled with potting mix soil and seedlings were thinned after emergence to one seedling per pot. Plants were grown out until reproductive stage, which were properly identified as Sumatran Fleabane at Herbarium of the State University of Paraná (UPCB) and at Institute of Biology - Herbarium Uberlandense at Federal University of Uberlândia.

\section{Greenhouse trials: Dose-response assays}

The $C$. sumatrensis plants were tested for the possible multiple resistance. A dose-response assay was carried out in a randomized block design with four replications, using herbicides of five different mode of action: photosystem-Ielectron diversion (PSI), protoporphyrinogen oxidase (PPO) inhibitors, photosystem II inhibitors (PSII), synthetic auxin and 5-enolypyruvyl-shikimate-3-phosphate synthase (EPSPS) inhibitors, represented by paraquat, saflufenacil, diuron, 2,4-D and glyphosate, respectively.

The experimental units were kept under greenhouse conditions and were irrigated daily. The recommend rate (1X) was defined to be $400 \mathrm{~g}_{\text {ai }} \mathrm{ha}^{-1}$ for paraquat, $70 \mathrm{~g}$ ai ha ${ }^{-1}$ for saflufenacil, 2,000 $\mathrm{g}$ ai ha ${ }^{-1}$ for diuron, 1,005 $\mathrm{g}$ ae ha- ${ }^{-1}$ for 2,4-D and $720 \mathrm{~g}$ ae ha ${ }^{-1}$ for glyphosate. A dose range of $0.5,1,2,4,8$ and 16 times $(X)$ the recommend dose were used. The nonreated plants were considered as control. Paraquat and saflufenacil were applied with non-ionic surfactant Agral 1\% and $0.5 \%(\mathrm{v} / \mathrm{v})$ (Agral ${ }^{\circledR}$, Syngenta Crop Protection, Greensboro, $\mathrm{NC})$, respectively. The treatments were sprayed to both biotypes (susceptible $-\mathrm{S}$ and suspected of resistance $-\mathrm{R}$ ).

\section{Herbicide spray}

The herbicide application was performed when the plants reached $12-15 \mathrm{~cm}$ height measured from the ground to the last leaf insertion. Herbicides treatments were applied using a $\mathrm{CO}_{2}$ pressurized backpack sprayer with four XR-110015 flat fan nozzles (TeeJet Technologies, Wheaton, IL), delivering $200 \mathrm{~L}$ $\mathrm{ha}^{-1}$ at $240 \mathrm{kPa}$.

\section{Injury and biomass analysis}

Visible injury and plant mortality was evaluated 28 days after treatment (DAT) compared to the non-treated control using a 0 to $100 \%$ scale, in which 0 was no effect and 100 as complete control (Velini et al., 1995) Plant growth reduction and dry mass evaluation of shoots was performed at 28 days after application (DAA). The plants were collected and dried in oven at $70^{\circ} \mathrm{C}$ for 72 hours and then weighed on scale. Biomass data were expressed as percentages of the non-treated mean control to standardize the comparisons among populations.

\section{Data analysis}

Plant mortality (LD) and reduction in plant growth (GR) were measured 28 DAT. After estimating $L_{50}$ (herbicide rate required to cause a $50 \%$ control) and $\mathrm{GR}_{50}$ (herbicide rate required to cause a $50 \%$ reduction in plant growth relative to nontreated plants) values using log-logistic models proposed by Streibig (1988) and Seefeldt et al. (1995):

$y=\frac{a}{\left[1+\left(\frac{x}{b}\right)^{c}\right]}$

Where; $y$ is the response based on visible injury estimate or dry weight, $a$ is the amplitude between the maximum and minimum point of the variable, $x$ is the dose of the herbicide ( $g$ a.i. $\mathrm{h}^{-1}$ ), $b$ is the herbicide dose giving a $50 \%$ response (plant mortality $\left[\mathrm{LD}_{50}\right]$ or growth reduction $\left[\mathrm{GR}_{50}\right]$ ) and $c$ is the inflection point around $b$.

The log-logistic model provided an estimate of the parameter $\mathrm{LD}_{50}$ or $\mathrm{GR}_{50}$. It was decided to use the mathematical calculation through the inverse equation making it possible to calculate the $\mathrm{LD}_{50}$ and $\mathrm{GR}_{50}$ :

$\mathrm{x}=\mathrm{b}\left(\left|\frac{\mathrm{a}}{\mathrm{y}}-1\right|\right)^{\frac{1}{\mathrm{c}}}$

The resistance index $(R I=R / S)$ were computed as R-to- $S L_{50}$ or $\mathrm{GR}_{50}$ ratios. The graphics were plotted using Sigma Plot 12.5 .

\section{Conclusion}

Based on our results, we can confirm multiple resistance of $C$. sumatrensis to five-mode-of-action to herbicides such as paraquat, saflufenacil, diuron, 2,4-D and glyphosate in ParanáBrazil. This is the first report of $C$. sumatrensis resistant to diuron and 2,4-D and the first case of $C$. sumatrensis with multiple resistant to five mode of action in the world. Research is underway to elucidate the mechanisms of resistance. In this moment, actions are being taken to monitor the areas, where the resistant biotypes were collected as well as other areas with biotypes suspected resistance. 


\section{Acknowledgment}

This work has been carried out with the support of the Corteva Agriscience ${ }^{\mathrm{TM}}$ Agriculture Division of DowDupont and HRAC Brazil. We would like to thank all support given to this work.

\section{Disclosure Statement}

The authors declare no conflicts of interest. ${ }^{\mathrm{T}}{ }^{\circledR}=$ Trademark of Dow AgrosSciences LLC, DuPont or Pioneer and their respective owners and their affiliated companies.

\section{References}

Adegas FS, Vargas L, Gazziero DLP, Karam D, da Silva AF, Agostinetto D (2017) Impacto econômico da resistência de plantas daninhas a herbicidas no Brasil. Embrapa Soja (Embrapa Soja. Circular técnica, 132). 7p.

Beckie HJ (2006) Herbicide-resistant weeds: management tactics and practices. Weed Technol. 20:793-814.

Beckie HJ, Tardif FJ (2012) Herbicide cross-resistance in weeds. Crop Prot. 35:15-28.

Beckie HJ, Harker KN (2017) Our top 10 herbicide-resistant weed management practices. Pest Manag Sci. 73:1045-1052.

Bostamam Y, Malone JM, Dolman FC, Boutsalis P, Preston C (2012) Rigid ryegrass (Lolium rigidum) populations containing a target site mutation in EPSPS and reduced glyphosate translocation are more resistant to glyphosate. Weed Sci. 60:474-479.

Burgos NR, Tranel PJ, Streibig JC, Davis VM, Shaner D, Norsworthy JK, Ritz C (2013) Review: confirmation of resistance to herbicides and evaluation of resistance levels. Weed Sci. 61:4-20.

Burgos, NR (2015) Whole-plant and seed bioassays for resistance confirmation. Weed Sci. 63:152-165.

Dayan FE, Trindade MLB, Velini ED (2009) Amicarbazone, a new photosystem II inhibitor. Weed Sci. 57:579-583

De Prado R, De Prado JL, Menendez J (1997) Resistance to substituted urea herbicides in Lolium rigidum biotypes. Pestic Biochem Phys. 57:126-136.

Délye C, Jasieniuk M, LeCorre V (2013) Deciphering the evolution of herbicide resistance in weeds. Trends Genet. 29:649-658.

Eubank TW, Nandula VK, Poston DH, Shaw DR (2012) Multiple resistance of horseweed to glyphosate and paraquat and its control with paraquat and metribuzin combinations. Agronomy. 2:358-370.

Ge X, d'Avignon DA, Ackerman JJH, Duncan B, Spaur MB, Sammons RD (2011) Glyphosate-resistant horseweed made sensitive to glyphosate: low-temperature suppression of glyphosate vacuolar sequestration revealed by 31P NMR. Pest Manag Sci. 67:1215-1221.

Ge X, d'Avignon DA, Ackerman JJ, Sammons D (2014) In vivo 31P-NMR studies of glyphosate uptake, vacuolar sequestration, and tonoplast pump activity in glyphosate resistant horseweed (Conyza canadensis). Plant Physiol. pp114.
Gharde Y, Singh PK, Dubey RP, Gupta PK (2018) Assessment of yield and economic losses in agriculture due to weeds in India. Crop Prot. 107:12-18.

Gonzalez-Torralva F, Brown AP, Chivasa S (2017) Comparative proteomic analysis of horseweed (Conyza canadensis) biotypes identifies candidate proteins for glyphosate resistance. Sci Rep. 7:42565. ichepi

González-Torralva F, Gil-Humanes J, Barro F, DomínguezValenzuela J A, De Prado R (2014) First evidence for a target site mutation in the EPSPS2 gene in glyphosate-resistant Sumatran fleabane from citrus orchards. Agron Sustain Dev. 34:553-560.

Hawkes TR (2014) Mechanisms of resistance to paraquat in plants. Pest Manag Sci. 70:1316-1323.

Heap I (2005) - Criteria for confirmation of herbicide-resistant weeds - with specific emphasis on confirming low level resistance.

http://www.weedscience.org/Documents/ResistanceCriterio n.pdf (Accessed January 10, 2018.

Heap I (2018) The international survey of herbicide resistant weeds. www.weedscience.org (Accessed January10, 2018).

Hilton HW (1957) Herbicide tolerant strains of weeds. Hawaiian Sugar Plant Assoc Annu Rep. 69.

Jha P, Kumar V, Godara RK, Chauhan BS (2017) Weed management using crop competition in the United States: A review. Crop Prot. 95:31-37.

Kaundun SS, Dale RP, Zelaya IA, Dinelli G, Marotti I, McIndoe E (2011) A novel P106L mutation in EPSPS and an unknown mechanism(s) act additively to confer resistance to glyphosate in a South African Lolium rigidum population. J Agric Food Chem. 59:3227-3233.

Kissmann KG, Groth D (1999) Plantas infestantes e nocivas. BASF, Brazil.

Kleinman Z, Rubin B (2017) Non-target-site glyphosate resistance in Conyza bonariensis is based on modified subcellular distribution of the herbicide. Pest manag sci. 73:246-253.

Kumar V, Jha P, Jhala AJ (2017) Confirmation of glyphosateresistant horseweed (Conyza canadensis) in montana cereal production and response to post herbicides. Weed Technol. 31:799-810.

Mellendorf TG, Young JM, Matthews JL, Young BG (2013) Influence of plant height and glyphosate on saflufenacil efficacy on glyphosate resistant horseweed (Conyza canadensis). Weed Technol. 27:463-467.

Mengistu LW, Mueller-Warrant GW, Liston A, Barker RE (2000) psbA mutation (valine219 to isoleucine) in Poa annua resistant to metribuzin and diuron. Pest Manag Sci. 56:209217.

Menne H (2005) Classification of herbicide site of action HRAC herbicide resistance action committee. http://www.racglobal.com/pages/classificationofherbicidesit eofaction. aspx (Accessed July 17, 2015).

Moreira MS, Nicolai M, Carvalho SJP, Christoffoleti PJ (2007) Resistência de Conyza canadensis e $C$ bonariensis ao herbicida glyphosate. Planta Daninha. 25:157-164. 
Moretti ML, Hanson BD (2017) Reduced translocation is involved in resistance to glyphosate and paraquat in Conyza bonariensis and Conyza canadensis from California. Weed Res. 57:25-34.

Moretti ML, Van Horn CR, Robertson R, Segobye K, Weller SC, Young, BG, d'Avignon A (2018) glyphosate resistance in Ambrosia trifida: part 2 rapid response physiology and nontarget-site resistance. Pest Manag Sci. 74:1079-1088.

Moretti M, Shrestha A, Hembree K, Hanson B (2015) Postemergence control of glyphosate/paraquat-resistant hairy fleabane (Conyza bonariensis) in tree nut orchards in the central valley of California. Weed Technol. 29:501-508.

Murphy CE, Lemerle D (2006) Continuous cropping systems and weed selection. Euphytica. 148:61-73.

Nandula VK, Ray JD, Ribeiro DN, Pan Z, Reddy KN (2013) Glyphosate resistance in tall waterhemp (Amaranthus tuberculatus) from Misissippi is due to both altered targetsite and nontarget-site mechanisms. Weed Sci. 61:374-383.

Nol N, Tsikou D, Eid M, Livieratos IC, Giannopolitis CN (2012) Shikimate leaf disc assay for early detection of glyphosate resistance in Conyza canadensis and relative transcript levels of EPSPS and ABC transporter genes. Weed Res. 52:233-241.

Norsworthy JK, Ward SM, Shaw DR, Llewellyn RS, Nichols RL, Webster TM (2012) Reducing the risks of herbicide resistance: best management practices and recommendations. Weed Sci. 60:31-62.

Page ER, Grainger CM, Laforest M, Nurse RE, Rajcan I, Bae J, Tardif FJ (2018) Target and non-target site mechanisms confer resistance to glyphosate in canadian accessions of Conyza canadensis. Weed Sci. 66:234-245.

Patzoldt WL, Hager AG, McCormick JS, Tranel PJ (2006) A codon deletion confers resistance to herbicides inhibiting protoporphyrinogen oxidase. Proc Natl Acad Sci USA. 103:12329-12334.

Perry DH, McElroy JS, Dane F, Van Santen E, Walker RH (2012) Triazine-resistant annual bluegrass (Poa annua) populations with Ser264 mutation are resistant to amicarbazone. Weed Sci. 60:355-359.

Peterson MA, Collavo A, Ovejero R, Shivrain V, Walsh MJ (2017) The challenge of herbicide resistance around the world: a current summary. Pest Manag Sci. 74:2246-2259.

Powles SB (2008) Evolved glyphosate-resistant weeds around the world: lessons to be learnt. Pest Manag Sci. 64:360-365.

Powles SB, Yu Q (2010) Evolution in action: plants resistant to herbicides. Annu Rev Plant Biol. 61:317-347.

Preston, C (2003) Inheritance and linkage of metabolism-based herbicide cross-resistance in rigid ryegrass (Lolium rigidum). Weed Sci. 51:4-12.

Preston C, Tardif FJ, Christopher JT, Powles SB (1996) Multiple resistance to dissimilar herbicide chemistries in a biotype of Lolium rigidum due to enhanced activity of several herbicide degrading enzymes. Pestic Biochem Phys. 54:123-134.

Preston C, Wakelin AM, Dolman FC, Bostamam Y, Boutsalis P (2009) A decade of glyphosate-resistant Lolium around the world: mechanisms, genes, fitness, and agronomic management. Weed Sci. 57:435-441.
Salas-Perez RA, Burgos NR, Rangani G, Singh S, Refatti JP, Piveta L, Tranel PJ, Mauromoustakos A, Scott RC (2017) Frequency of Gly-210 deletion mutation among protoporphyrinogen oxidase inhibitor-resistant palmer amaranth (Amaranthus palmeri) populations. Weed Sci. 65:718-731.

Salas RA, Burgos NR, Tranel PJ, Singh S, Glasgow L, Scott RC, Nichols RL (2016) Resistance to PPO-inhibiting herbicide in Palmer amaranth from Arkansas. Pest Manag Sci. 72:864869.

Sammons RD, Gaines TA (2014) Glyphosate resistance: state of knowledge. Pest Manag Sci. 70:1367-1377.

Santos G, Oliveira Jr RS, Constantin J, Francischini AC, Machado MF, Mangolin CA, Nakajima JN (2014) Conyza sumatrensis: A new weed species resistant to glyphosate in the Americas. Weed Biol Manag. 14:106-114.

Santos G, Oliveira Jr. RS, Constantin J, Francischini AC, Osipe JB (2014) Multiple resistance of Conyza sumatrensis to chlorimuronethyl and to glyphosate. Planta Daninha. 32:409416.

Savage D, Borger CP, Renton M (2014) Orientation and speed of wind gusts causing abscission of wind-dispersed seeds influences dispersal distance. Funct Ecol. 28:973-981.

Seefeldt SS, Jensen JE, Fuerst EP (1995) Log-logistic analysis of herbicide dose-response relationships. Weed Technol. 9:218227.

Streibig JC (1988) Herbicide bioassay. Weed Res. 28:479-84.

Swanton CJ, Nkoa R, Blackshaw RE (2015) Experimental methods for crop-weed competition studies. Weed Sci. 63:211.

Switzer CM (1957) The existence of 2,4-D resistant strains of wild carrot. Proc. Northeast Weed Control Conf. 11:315-318.

Szigeti Z (2005) Mechanism of paraquat resistance - from the antioxidant enzymes to the transporters. Acta Biol Szeged. 49:177-179.

Tani E, Chachalis D, Travlos IS (2015) A glyphosate resistance mechanism in Conyza canadensis involves synchronization of EPSPS and ABC-transporter genes. Plant Mol Biol. 33:17211730.

Tozzi E, Van Acker RC (2014) Effects of seedling emergence timing on the population dynamics of horseweed (Conyza canadensis var. canadensis). Weed Sci. 62:451-456.

Van Gessel MJ, Scott BA, Johnson QR (2006) Paraquat-resistant horseweed identified in the Mid-Atlantic States. Crop Manag. 5 (1).

Van Horn CR, Moretti ML, Robertson RR, Segobye K, Weller SC, Young BG (2017) Glyphosate resistance in ambrosia trifida: I novel rapid cell death response to glyphosate. Pest Manag Sci. 74:1071-1078

Velini ED, Osipe R, Gazziero DLP (1995) Procedimentos para instalação, avaliação e análise de experimentos com herbicidas SBCPD. Brazil.

Waggoner BS, Mueller TC, Bond JA, Steckel LE (2013) Control of glyphosate-resistant horseweed (Conyza canadensis) with saflufenacil tank mixtures in no-till cotton. Weed Technol. 25:310-315. 
Werth J, Walker S, Boucher L, Robinson G (2010) Applying the double knock technique to control Conyza bonariensis. Weed Biol and Manag. 10:1-8.

Wu H, Walker S, Rollin MJ, Tan DKY, Robinson G, Werth J (2007) Germination, persistence, and emergence of flaxleaf fleabane (Conyza bonariensis [L.] Cronquist). Weed Biol. Manag. 7:192-199.

Ye B, Gressel J (2000) Transient, oxidant-induced antioxidant transcript and enzyme levels correlate with greater oxidantresistance in paraquat-resistant Conyza bonariensis. Planta. 211:50-61.
Yu J, McCullough PE, Vencill WK (2013) Absorption, translocation, and metabolism of amicarbazone in annual bluegrass (Poa annua), creeping bentgrass (Agrostis stolonifera), and tall fescue (Festuca arundinacea). Weed Sci. 61:217-221.

Yu $Q$, Jalaludin A, Han $H$, Chen $M$, Sammons RD, Powles SB (2015) Evolution of a double amino acid substitution in the 5enolpyruvylshikimate-3-phosphate synthase in Eleusine indica conferring high-level glyphosate resistance. Plant Physiol.167:1440-1447.

Yuan JS, Tranel PJ, Stewart CN (2007) Non-target-site herbicide resistance: a family business. Trends Plant Sci. 12:6-13. 